\title{
Carcinogenicity of deoxycholate, a secondary bile acid
}

\author{
Carol Bernstein - Hana Holubec $\cdot$ Achyut K. Bhattacharyya \\ Huy Nguyen · Claire M. Payne · Beryl Zaitlin · Harris Bernstein
}

Received: 4 October 2010/ Accepted: 10 January 2011/Published online: 26 January 2011

(C) The Author(s) 2011. This article is published with open access at Springerlink.com

\begin{abstract}
High dietary fat causes increased bile acid secretion into the gastrointestinal tract and is associated with colon cancer. Since the bile acid deoxycholic acid (DOC) is suggested to be important in colon cancer etiology, this study investigated whether DOC, at a high physiologic level, could be a colon carcinogen. Addition of $0.2 \%$ DOC for $8-10$ months to the diet of 18 wild-type mice induced colonic tumors in 17 mice, including 10 with cancers. Addition of the antioxidant chlorogenic acid at $0.007 \%$ to the DOC-supplemented diet significantly reduced tumor formation. These results indicate that a high fat diet in humans, associated with increased risk of colon cancer, may have its carcinogenic potential mediated through the action of bile acids, and that some dietary antioxidants may ameliorate this carcinogenicity.
\end{abstract}

Keywords Colon cancer - Deoxycholate ·

Adenocarcinoma $\cdot$ Chlorogenic acid

C. Bernstein $(\square) \cdot$ H. Holubec $\cdot$ H. Nguyen

C. M. Payne $\cdot$ H. Bernstein

Department of Cell Biology and Anatomy, College of Medicine,

University of Arizona, Tucson, AZ 85724-5044, USA

e-mail: bernstein3@earthlink.net

A. K. Bhattacharyya - C. M. Payne $\cdot$ H. Bernstein Arizona Cancer Center, University of Arizona,

Tucson, AZ, USA

\section{A. K. Bhattacharyya}

Department of Pathology, College of Medicine,

University of Arizona, Tucson, AZ, USA

B. Zaitlin

Department of Civil Engineering, University of Calgary,

Calgary, AB, Canada

\section{Introduction}

The primary cause of sporadic colorectal cancer appears to be diet, although inherited mutations and smoking are also risk factors. In human populations, colon cancer development is associated with a high fat diet (Drasar and Irving 1973; Knox 1977; Miller et al. 1983; McKeown-Eyssen and Bright-See 1984; Willett 1989; Willett et al. 1990; Hursting et al. 1990; Butler et al. 2009). When a high fat diet is fed to cancer prone $A p c^{\mathrm{min} /+}$ mice, a significant increase in intestinal tumors is observed (Wasan et al. 1997). A Western-style diet containing a high level of lipids and a low level of calcium and vitamin $\mathrm{D}$ induces colonic tumors in normal mice (Newmark et al. 2001, 2009; Yang et al. 2008). These studies implicate dietary fat in the etiology of human colorectal cancer. However, it should be noted that the type of fat is also important, as omega-3 polyunsaturated fatty acids are reported to decrease colon cancer incidence (La Vecchia 2009; Tavani et al. 2003).

The bile acids deoxycholic acid (DOC) and lithocholic acid are increased in the colonic contents of humans in response to a high fat diet (Reddy et al. 1980). The increase in these bile acids presumably reflects increased deposition of bile acids in the gastrointestinal tract in order to emulsify the increased level of dietary fat. In populations with a high incidence of colorectal cancer, fecal concentrations of bile acids are increased (Hill 1990; Cheah 1990; Hill et al. 1982; Crowther et al. 1976; Reddy and Wynder 1973; Reddy et al. 1978; Jensen et al. 1982), suggesting that increased exposure of the colonic lumen to high levels of bile acids plays a role in the natural course of development of colon cancer. In addition, Bayerdorffer et al. (1995) reported a positive association between DOC in the serum and colorectal adenomas, the precursors of colorectal 
cancer, further indicating a pathogenic role of DOC in colonic carcinogenesis. The hydrophobic bile acids, DOC and lithocholic acid, appear to be the most significant bile acids with respect to human colorectal cancer (Hill 1990).

In addition to evidence from population studies (Hill 1990; Cheah 1990; Hill et al. 1971, 1982; Crowther et al. 1976; Reddy and Wynder 1973; Reddy et al. 1978; Jensen et al. 1982), experimental evidence also strongly indicates an etiologic role of bile acids in colon cancer. Figure 1 indicates the mechanism by which high levels of bile acids in the colon could lead to colon cancer. Exposure of colon cells to high physiologic concentrations of DOC induces formation of reactive oxygen and nitrogen species (Lechner et al. 2002; Crowley-Weber et al. 2003; Casellas et al. 1996; Venturi et al. 1997; Booth et al. 1997; WashoStultz et al. 1999, 2002; Payne et al. 2007; Longpre and Loo 2008; Dall'Agnol et al. 2006; Craven et al. 1986; Bernstein et al. 2006) and DNA damage (Venturi et al. 1997; Booth et al. 1997; Longpre and Loo 2008; Bernstein et al. 2006; Payne et al. 1998; Rosignoli et al. 2008; Booth and Bilton 1998; Powolny et al. 2001; Glinghammar et al. 2002; Romagnolo et al. 2003) (Fig. 1). The DNA damage induced by DOC is, in part, oxidative DNA damage (Venturi et al. 1997; Bernstein et al. 2006; Rosignoli et al. 2008). Deficiency in base excision repair of oxidative DNA damage is linked to increased risk of intestinal tumors in mice (Sakamoto et al. 2007) and of colon cancer in humans (Jenkins et al. 2006). That DOC induces DNA damage in colon cells suggests that bile acids may also cause mutation (Fig. 1) when replication occurs past the damage. Recently, we showed that DOC causes aneuploidy and micronuclei formation, indicators of genomic instability, in colon epithelial cells (Payne et al. 2008, 2010a). Furthermore, persistent exposure of cultured colon epithelial cells to DOC results in altered expression of chromosomal maintenance/ mitosis-related genes that might account, in part, for the observed genomic instability (Payne et al. 2008, 2010a; Crowley-Weber et al. 2002; Bernstein et al. 2004).

Numerous studies have shown that DOC induces apoptosis in colon cells in short-term cultures (Fig. 1) (e.g. Washo-Stultz et al. 1999; Longpre and Loo 2008; Booth and Bilton 1998; Glinghammar et al. 2002; Sakamoto et al. 2007; Payne et al. 1995; Garewal et al. 1996; Bernstein et al. 1999, 2002). Induction of apoptosis after cells encounter DOC may protect against the survival of cells with damaged template DNA that, upon replication, might undergo mutation leading to cancer. In the long-term, however, repeated exposure of colonic epithelial cells to high physiologic concentrations of bile acids appears to select for cells that are resistant to induction of apoptosis by bile acids (Payne et al. 1995, 2007; Garewal et al. 1996; Bernstein et al. 1999, 2002) (Fig. 1). Epithelial cells of colonic origin that were grown in culture and repeatedly exposed to

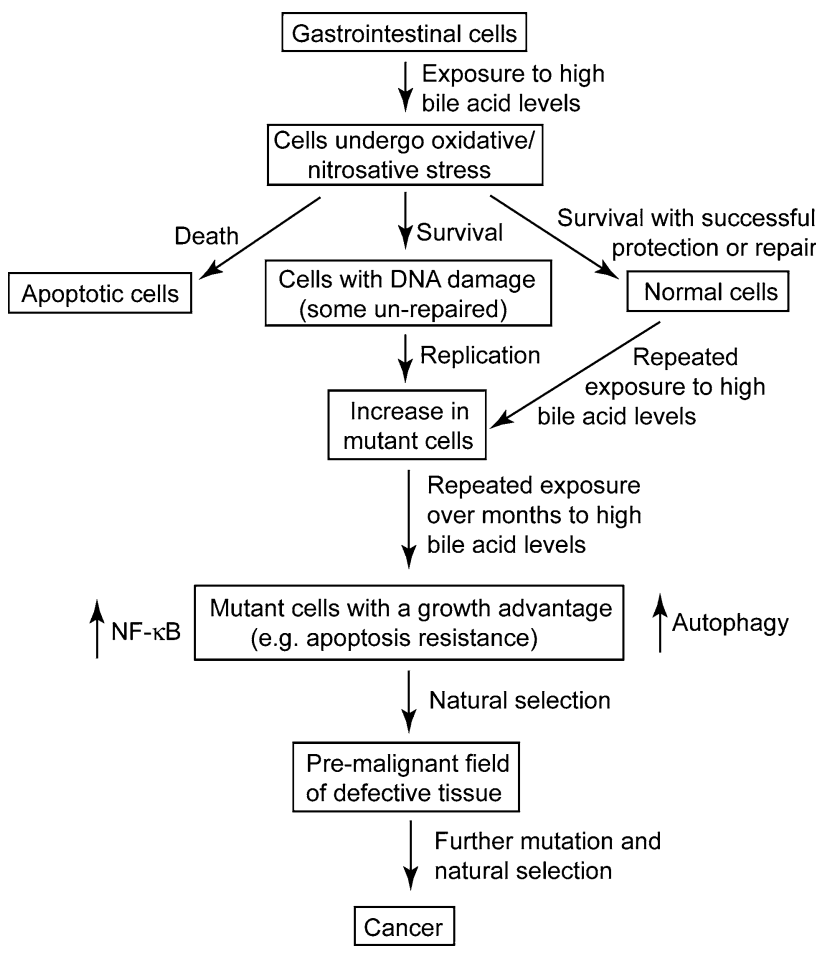

Fig. 1 Role of bile acids in progression to cancer

increasing concentrations of DOC developed resistance to apoptosis. These apoptosis-resistant cells were altered in expression in 839 out of 5,000 genes assessed by cDNA assay (Crowley-Weber et al. 2002) and in 91 of 454 proteins detected by a proteomic analysis (Bernstein et al. 2004). The autophagic survival pathway was also determined to be responsible, in part, for the observed apoptosis resistance of these cells (Fig. 1) (Payne et al. 2009). Apoptosis-resistant cells might arise in vivo through mutation (or epimutation) and clonally expand through natural selection to form a field of resistant cells (Fig. 1). Evidence for such a "field change" is the observation that expression of the antiapoptotic protein $\mathrm{Bcl}-\mathrm{xL}$ is increased in the colon mucosa adjacent to adenocarcinomas (Badvie et al. 2006). Also a variant of the ileal bile acid binding protein, referred to as IBABP-L, is up-regulated in colorectal cancer and is necessary for resistance of these cancer cells to hydrophobic bile acids (Fang et al. 2007), indicating that resistance to bile acid-induced apoptosis plays a role in colon carcinogenesis.

The findings briefly reviewed above suggest that frequent stimulation of bile acid deposition into the gastrointestinal tract, due to elevated dietary fats/oils, plays a key role in the induction of colonic tumors. Recently we reported that exposure of mouse colon to dietary DOC induced colitis (Bernstein et al. 2006, 2007) and sessile adenomas (Payne et al. 2010b). We also showed that dietary DOC modulated the expression of at least 95 mouse genes at the mRNA level, including genes involved in the 
processes of inflammation, angiogenesis, epithelial barrier function, oxidative stress, apoptosis, cell proliferation/cell cycle/DNA repair, membrane transport and the ubiquitinproteasome pathway (Bernstein et al. 2006). In the present study, we report that DOC not only induces adenomas, but also invasive cancers. We also present evidence that dietary chlorogenic acid (high in coffee, blueberries, eggplant and apples) inhibits tumor development in mice fed the DOC-supplemented diet.

\section{Materials and methods}

Animals

Mice were maintained at the University of Arizona's Animal Care Facility. Wild-type male B6.129PF2/J mice were obtained from Jackson Laboratories (Bar Harbor, $\mathrm{ME}$ ). All animals were raised in cages under non-sterile micro-isolator conditions and in compliance with the regulations and NIH guidelines for Care and Use of Laboratory Animals.

The mice were free of murine viruses, pathogenic bacteria (including Helicobacter spp.), and endo- and ectoparasites by routine health evaluations. The mice were maintained on a 12-hr light-dark cycle with water ad libitum and fed a purified AIN-93G diet, either non-supplemented (diet 1), supplemented with $0.2 \%$ DOC (diet 2), $0.007 \%$ chlorogenic acid (CGA) (diet 3), or $0.2 \%$ $\mathrm{DOC}+0.007 \%$ CGA (diet 4). The purified diets were prepared by Harlan Teklad (Madison, WI). The AIN-93G diet components and analysis are shown in Table 1. Mice

Table 1 AIN93G diet components and analysis

\begin{tabular}{ll}
\hline & $\mathrm{g} / \mathrm{Kg}$ \\
\hline Casein & 200.000 \\
L-cystine & 3.000 \\
Corn starch & 397.486 \\
Maltodextrin & 132.000 \\
Sucrose & 100.000 \\
Soybean oil & 70.000 \\
Cellulose & 50.00 \\
AIN-93G mineral mix & 35.000 \\
AIN-93G vitamin mix & 10.000 \\
Choline bitartrate & 2.500 \\
t-Butylhydroquinone & 0.014 \\
Protein & $18.7 \%$ \\
Fat & $7.0 \%$ \\
Fiber & $5.0 \%$ \\
Carbohydrate & $64.7 \%$ \\
Metabolizable energy & $3.97 \mathrm{kcal} / \mathrm{gm}$ \\
\hline
\end{tabular}

were fed the diets starting at 5 weeks of age and continuing until termination. Mice were sacrificed using $\mathrm{CO}_{2}$ at 8 or 10 months of feeding.

Histopathology and photography

The whole colon was removed, opened longitudinally, rinsed with phosphate-buffered saline, divided into 3 segments, the segments were placed flat on a Matricel membrane for orientation, photography of opened segments was performed on some segments with a Sony Cybershot 7.2 megapixel camera, segments were fixed in $10 \%$ formalin overnight at $4^{\circ} \mathrm{C}$, transferred to $70 \%$ alcohol, and embedded in paraffin.

Then 4 micron tissue sections were cut and placed on a slide for histopathological assessment after staining with hematoxylin and eosin. Morphologic evaluation was performed using a brightfield microscope (Nikon E400). Representative images were captured digitally using a Sony 3CCD color videocamera and ImagePro software (Media Cybernetics, Silver Spring, MD).

Measurement of DOC in the feces

DOC was measured in the mixed feces of four mice on each of two diets (control, diet + DOC) after 90 days on their diets. Similar to the method described by Post et al. (2003), fecal production during a 1-day period was separated from the bedding, fecal samples were frozen at $-80^{\circ} \mathrm{C}$, lyophilized, and for analysis of bile acids, an aliquot of dried feces ( $5 \mathrm{mg}$ ) was used. The feces were analyzed for bile acids by a standard method used previously in the core facilities at the Arizona Cancer Center for measuring DOC in human feces (Alberts et al. 2005; Wertheim et al. 2009). The dried feces were incubated in $1 \mathrm{ml}$ alkaline methanol (methanol:

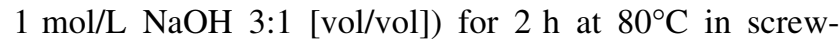
capped tubes, using added norcholic acid as an internal standard. The procedure was then continued as described (Alberts et al. 2005; Wertheim et al. 2009) using a ThermoFinnigan TSQ Quantum triple quadrupole mass spectrometer in tandem with a Surveyor LS system.

Data analysis

As the data was non-normally distributed, the nonparametric Mann-Whitney $U$ test was used to test for differences between diets.

\section{Results}

Mice were fed either a control non-supplemented diet (diet 1), a diet supplemented with $0.2 \%$ DOC (diet 2), a diet 
supplemented with $0.007 \%$ chlorogenic acid (CGA) (diet 3) or a diet supplemented with both DOC and CGA (diet 4). The presence of DOC in the feces of 4 mice on the control diet and 4 mice on the diet + DOC was measured after 90 days on their diets. The level of DOC in feces from mice on the control diet was $0.3 \mathrm{mg}$ DOC/g dry weight, while the level of fecal DOC for mice on the diet + DOC was $4.6 \mathrm{mg} \mathrm{DOC/g}$ dry weight.

The mice fed each of the 4 diets had colons that, in most areas, appeared to be morphologically normal (Fig. 2). However, the wild-type mice fed a diet supplemented with $0.2 \%$ DOC (diet 2 ) frequently developed tumors that could be seen macroscopically when the mouse colons were opened (Fig. 3). Mouse tumors after 8 months on the DOC-supplemented diets, when viewed macroscopically, appeared to be more distinct, with more defined borders than tumors seen after 10 months on a DOC-supplemented diet, when tumors appeared to have less defined margins and were often more spread out (broad based or sessile).

When hematoxylin and eosin stained sections were viewed by brightfield microscopy, sessile adenomas, sessile-serrated adenomas (Fig. 4 panels A, B) and adenocarcinomas (Fig. 4 panels C, D) could be identified histopathologically in the colons of mice whose diets were supplemented with DOC or DOC + CGA for 8 or 10 months (Table 2).

As shown in Table 2, 17 of 18 mice (94\%) fed the DOC supplemented diet for 8 or 10 months developed tumors (adenomas or cancers), and of these DOC-fed mice, 10 (56\%) had developed cancers. The 12 mice without any supplement to their diet had no tumors or cancers. At 8 and 10 months, there were significant differences in the number of mice with tumor development between those fed a DOC-supplemented diet and those fed no supplements (8-month Mann-Whitney $U=0.00, n_{1}=12, n_{2}=6$, $P<0.001$ two-tailed; 10 -month Mann-Whitney $U=3.00$, $n_{1}=6, n_{2}=6, P=0.005$ two-tailed). Similarly, the development of cancers in DOC fed mice compared to the non-supplemented mice was clearly significant at both 8 and 10 months (8-month Mann-Whitney $U=18.00$, $n_{1}=12, n_{2}=6, P=0.039$ two-tailed; 10-month MannWhitney $U=6.00, n_{1}=6, n_{2}=6, P=0.019$ twotailed).

When CGA at $0.007 \%$ (a level equivalent to 3 cups of coffee a day in humans (Clifford 1999)) was added along with DOC (DOC + CGA diet), the number of mice that developed tumors was significantly reduced in comparison to the mice on a diet supplemented with DOC alone at 8 months, but not at 10 months (8-month Mann-Whitney $U=24.00, \quad n_{1}=12, \quad n_{2}=6, \quad P=0.039 \quad$ two-tailed; 10-month Mann-Whitney $U=11.50, n_{1}=6, n_{2}=5$, $P=0.409$ two-tailed). The tumor burden in the DOC-fed mice at 8 months was 1.6 times the tumor burden in the DOC + CGA-fed mice (Table 2), and the cancer burden in the DOC-fed mice at 8 months was 3 times the cancer burden in the DOC + CGA-fed mice (Table 2).

The frequency of mice with tumors was significantly higher on the DOC + CGA diet vs. no supplement at both 8 and 10 months (8-month Mann-Whitney $U=6.00$, $n_{1}=6, n_{2}=6, P=0.019$ two-tailed; 10-month MannWhitney $U=6.00, n_{1}=5, n_{2}=6, P=0.034$ two-tailed), but the frequency of mice with cancers was not significantly different at 8 or 10 months (8-month Mann-Whitney $U=15.00, \quad n_{1}=6, \quad n_{2}=6, \quad P=0.317 \quad$ two-tailed;

Table 2 Effect of DOC and CGA in diet on tumor and cancer development

\begin{tabular}{|c|c|c|c|c|c|c|}
\hline $\begin{array}{l}\text { Added to } \\
\text { AIN93 diet }\end{array}$ & $\begin{array}{l}\text { Months } \\
\text { on diet }\end{array}$ & $\begin{array}{l}\text { Number } \\
\text { of mice }\end{array}$ & $\begin{array}{l}\text { Mice with tumors } \\
\text { (adenomas }+ \text { cancers) }\end{array}$ & $\begin{array}{l}\text { Mice with } \\
\text { cancer }\end{array}$ & $\begin{array}{l}\text { Number of tumors } \\
\text { (tumor burden**) }\end{array}$ & $\begin{array}{l}\text { Number of cancers } \\
\text { (cancer burden***) }\end{array}$ \\
\hline \multirow[t]{3}{*}{ DOC } & 8 & 12 & $12(100 \%)$ & $6(50 \%)$ & $16(1.3)$ & $7(0.6)$ \\
\hline & 10 & 6 & $5(83 \%)$ & $4(67 \%)$ & $13(2.2)$ & $8(1.3)$ \\
\hline & & Total 18 & Total $17(94 \%)$ & Total $10(56 \%)$ & Total 29 (1.6) & Total $15(0.83)$ \\
\hline \multirow[t]{3}{*}{$\mathrm{DOC}+\mathrm{CGA}$} & 8 & 6 & $4(67 \%)$ & $1(17 \%)$ & $5(0.8)$ & $1(0.2)$ \\
\hline & 10 & 5 & $3(60 \%)$ & $1(20 \%)$ & $5(1.0)$ & $1(0.2)$ \\
\hline & & Total 11 & Total $7(64 \%)$ & Total $2(18 \%)$ & Total $10(0.9)$ & Total $2(0.2)$ \\
\hline \multirow[t]{3}{*}{ CGA } & 8 & 6 & 0 & 0 & 0 & 0 \\
\hline & 10 & 6 & 0 & 0 & 0 & 0 \\
\hline & & Total 12 & Total 0 & Total 0 & Total 0 & Total 0 \\
\hline \multirow[t]{3}{*}{ None } & 8 & 6 & 0 & 0 & 0 & 0 \\
\hline & 10 & 6 & 0 & 0 & 0 & 0 \\
\hline & & Total 12 & Total 0 & Total 0 & Total 0 & Total 0 \\
\hline
\end{tabular}

DOC deoxycholate, CGA chlorogenic acid

** Tumor burden is the ratio of the number of tumors observed to the number of mice

*** Cancer burden is the ratio of the number of cancers observed to the number of mice 
Fig. 2 Normal areas of colons of mice from 4 different dietary groups. Diet supplements fed for 10 months: a none; b CGA; c DOC; $\mathbf{d} \mathrm{DOC}+\mathrm{CGA}$. Images taken at $200 \times$ magnification. Bars show $0.2 \mathrm{~mm}$. H\&E staining

Fig. 3 Opened mouse proximal colon segments showing tumors after feeding the DOC-

supplemented diet. Each opened colon segment is shown (top images), with the

macroscopically observed tumors identified with closed dashed curves (bottom images). Left images: 8 months on diet; Right images: 10 months on diet

Fig. 4 Two areas of mouse colonic mucosa with sessile serrated adenomas $(\mathbf{a}, \mathbf{b})$ and two areas with adenocarcinomas (c with a stage $\mathrm{T} 1$, and $\mathbf{d}$ with a stage T2 cancer). From mice fed the DOC supplemented diet for 10 months. Images taken at $200 \times$ magnification. Bars show $0.2 \mathrm{~mm}$. H\&E staining
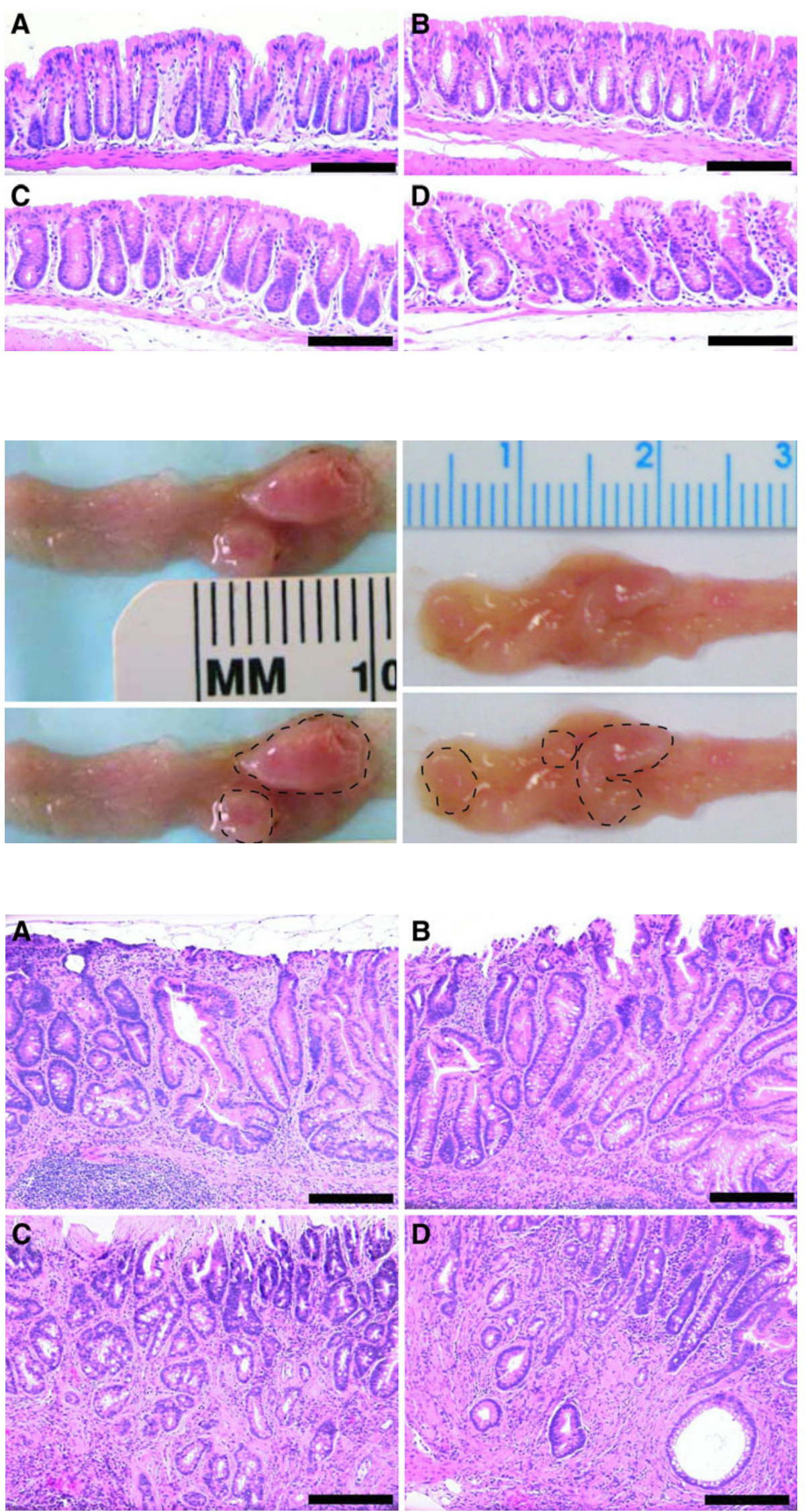
10-month Mann-Whitney $U=9.00, n_{1}=5, n_{2}=6, P=$ 0.102 two-tailed).

Similarly, the frequency of mice with tumors on the DOC + CGA diet was significantly higher than the frequency of mice with tumors on the CGA diet alone at both 8 and 10 months (8-month Mann-Whitney $U=6.00$, $n_{1}=6, n_{2}=6, P=0.019$ two-tailed; 10-month MannWhitney $U=6.00, \quad n_{1}=5, \quad n_{2}=6, P=0.034$ twotailed), but the frequency of mice with cancers was not significantly different at 8 or 10 months (8-month MannWhitney $U=15.00, n_{1}=6, n_{2}=6, P=0.317$ two-tailed; 10-month Mann-Whitney $U=9.00, n_{1}=5, n_{2}=6, P=$ 0.102 two-tailed).

All of the tumors in the DOC-fed mice were in the same region, the proximal colon. Furthermore, all of the tumors were sessile, and $71 \%$ of these were sessile-serrated adenomas or adenocarcinomas arising from sessile serrated adenomas. Of the 17 cancers observed (15 in the DOC fed mice, and 2 in the DOC + CGA fed mice), all appeared to arise from sessile-serrated adenomas. The adenocarcinomas were classified with regard to the extent of spread through the layers that form the wall of the colon. Fourteen $(82 \%)$ of the adenocarcinomas were in category $\mathrm{T} 1$ (the cancer had grown through the muscularis mucosa and extended into the submucosa) (Fig. 4c), and 3 (18\%) of the adenocarcinomas were T2 (the cancer had grown through the submucosa and into the muscularis propria) (Fig. 4d). All tumors were found in the colon. No tumors were observed in the small intestine.

Body weights of the mice fed the diets plus supplements (DOC, DOC + CGA, or CGA) did not differ from body weights of mice fed the non-supplemented AIN-93G diet.

\section{Discussion}

Early experiments on rats showed that bile acids can act as promoters, enhancing the incidence of tumors when a potent carcinogen was also administered (Narisawa et al. 1974; Reddy et al. 1976, 1977; McSherry et al. 1989). However, in these previous rat experiments, bile acid treatment alone did not induce tumors. In the first of these studies (Narisawa et al. 1974) the bile acids lithocholic and taurodeoxycholic acid were administered intrarectally; in the second study (Reddy et al. 1976) DOC was administered intrarectally to germ free rats; in the third study (Reddy et al. 1977) cholic acid and chenodeoxycholic acid were administered intrarectally; and in the fourth study (McSherry et al. 1989) cholic acid was fed, but only over a 6 month period. These prior experiments differed from those reported here in several ways [i.e. rats vs. mice; intrarectal vs. dietary (oral) administration; various other bile acids vs. DOC; germ free vs. conventional rodents;
6 months vs. 8-10 months of exposure]. Thus, there is no inconsistency between these early negative results and the positive results reported here, where adding DOC to the diet of mice for 8-10 months caused development of colon cancer.

All of the tumors found in this study were in the proximal colon of the mice. In humans, however, tumors are found both in the proximal and distal regions of the colon. The level of DOC in the different regions of the human colon depends on two factors. The first factor is the continuous deconjugation and dehydroxylation (by bacteria) of the cholic acid entering from the small intestine, which forms new DOC throughout the length of the colon (Thomas et al. 2001). The second factor is the high level of absorption (about 50\% overall) of DOC as it passes along all the regions of the colon (Samuel et al. 1968). In our mice, the level of DOC (from the diet of our diet + DOC fed mice) is already high in the proximal region of the colon. Conversion of cholic acid to DOC would be relatively insignificant for these mice since about $90 \%$ of the DOC in the colons of our mice fed diet + DOC comes from the added DOC in the diet. Presumably, there is similar absorption of DOC from all regions of the colon in mice, as occurs in humans. Thus, there should be higher levels of DOC in the proximal colons of our mice compared to the levels of DOC in their distal colons. In our mice, much of the DOC would be absorbed as it travels down the length of the mouse colon. If tumors are caused by interaction of relatively high levels of DOC with colonic epithelial cells, then it is likely that, in our system, most tumors would occur in the proximal colons of the mice, while in humans, with a more even distribution of DOC along the colon, tumors would occur in both the proximal and distal regions of the colon.

All the tumors we observed were of the sessile type, and most were sessile-serrated. In humans, about $9 \%$ of colonic tumors found by colonoscopy are sessile-serrated adenomas (Spring et al. 2006). Patients with a sessile-serrated adenoma were estimated to develop a subsequent adenocarcinoma at a rate of $5.3 \%$, compared with a rate of $2.2 \%$ for conventional adenoma patients (Noffsinger 2009).

The dietary level of DOC used in this study $(0.2 \%)$ to induce colon adenomas and colonic adenocarcinomas produced a level of DOC in dried feces, after 90 days on diet + DOC, of $4.6 \mathrm{mg}$ DOC/g dry weight, while the level of DOC in dried feces from mice on the control diet for 90 days was $0.3 \mathrm{mg}$ DOC/g dry weight.

For humans on a non-controlled omnivorous diet the level of DOC in the feces varies from $2.3 \mathrm{mg} / \mathrm{g}$ dry weight to $4.1 \mathrm{mg} / \mathrm{g}$ dry weight with a mean of $3.2 \mathrm{mg} / \mathrm{g}$ dry weight (Reddy et al. 1998). Two different experimental high fat diets in humans raised levels of DOC in the feces by approximately a factor of 2 , compared to humans eating a 
non-intervention diet (Reddy et al. 1980; Stadler et al. 1988). Thus, a high fat human diet would subject humans to colonic exposure to DOC at an average value in their feces of $2 \times 3.2 \mathrm{mg} / \mathrm{g}=6.4 \mathrm{mg} / \mathrm{g}$ dry weight, a level that is similar to the level of colonic exposure to DOC in our mice fed a DOC-supplemented diet (4.6 mg DOC/g dry weight in their feces). These levels of DOC in the feces of humans and mice were evaluated by use of a mass spectrometer. Such evaluations do not discriminate between conjugated and non-conjugated bile acid concentrations, and thus could overestimate the total amount of non-conjugated DOC in the feces. However, as shown by Reddy et al. (1998), conjugated bile acids were $0.75 \mathrm{mg} / \mathrm{g}$ dry weight in omnivores while free bile acids were $7.48 \mathrm{mg} / \mathrm{g}$ dry weight. Since conjugated bile acids are only a small fraction of the total bile acids in the colon [0.75/ $(7.48+0.75)=0.09$ ] our comparison of the level of DOC in the feces of humans and mice is not significantly changed.

Both of the experimental high fat human diets specified consumption of about $120 \mathrm{~g}(4.3 \mathrm{oz})$ per day of fat, either from whole milk products and beef (Reddy et al. 1980) or from corn oil (Stadler et al. 1988). This is comparable to the daily fat consumption of present-day Americans who consume at the high end of the spectrum of high-fat diets [this could be over 150 grams $(5.3 \mathrm{oz})$ of fat per day]. Such individuals would likely be exposed to increased levels of DOC in their colons, comparable to the levels to which our DOC-fed mice were exposed.

DOC is a natural endogenous agent increased in the colonic contents of humans in response to a high fat diet. Our results show that DOC can act as a carcinogen. These findings mesh with a substantial body of epidemiological findings, as well as experimental evidence at the cellular level, which also indicate that bile acids have a major etiologic role in colon cancer in humans (reviewed in the Introduction, above, and more extensively in Jenkins et al. 2006; Bernstein et al. 2005, 2009).

The finding that chlorogenic acid, added to the DOCsupplemented diet of 11 mice, significantly reduced tumor development suggests that chlorogenic acid may prove to be effective in inhibiting tumor development in humans. Such a potential effect is also suggested by the finding for humans, in two large prospective cohort studies, of an approximately twofold lower risk of rectal cancer associated with regular consumption of decaffeinated coffee (Michels et al. 2006). Coffee has a high level of chlorogenic acid (Clifford 1999; Mattila and Kumpulainen 2002). Chlorogenic acid has antioxidant activity in vitro and consumption of blueberries high in chlorogenic acid, increased plasma antioxidant capacity by $15 \%$ (FernandezPanchon et al. 2008). Further, chlorogenic acid protects DNA against oxidative damage in vitro (Tang and Liu
2008). Chlorogenic acid does not confer chemoprotection against azoxymethane-induced colon carcinogenesis in mice (Park et al. 2010). Thus it appears that chlorogenic acid is protective in the likely naturally occurring DOCinduced pathway to colon cancer, but not in the azoxymethane-induced colon carcinogenesis pathway, which may not be similar to the natural pathway. Overall, our findings suggest that bile acids, at the high physiologic levels and long-term exposures associated with a high fat Western diet, may act as carcinogens in the development of colon cancer in humans, and that chlorogenic acid may ameliorate this effect.

Acknowledgments We wish to thank Gillian Paine, of the Arizona Cancer Center Experimental Mouse Shared Service Facility for overseeing the mouse experiments and Karen Blohm-Mangone for maintaining the mice. We also thank Andrea Grantham for cutting the tissue sections and the H\&E staining. Supported in part by NIH 5 RO1 CA119087; Arizona Biomedical Research Commission Grant \#0803; Department of Veterans Affairs, Veterans Health Administration, Office of Research and Development, VA Merit Review Grant 0142 of the Southern Arizona Veterans Affairs Health Care System; and Biomedical Diagnostics and Research, Inc., Tucson, Arizona.

Open Access This article is distributed under the terms of the Creative Commons Attribution Noncommercial License which permits any noncommercial use, distribution, and reproduction in any medium, provided the original author(s) and source are credited.

\section{References}

Alberts DS, Martínez ME, Hess LM, Einspahr JG, Green SB, Bhattacharyya AK, Guillen J, Krutzsch M, Batta AK, Salen G, Fales L, Koonce K, Parish D, Clouser M, Roe D, Lance P (2005) Phoenix and Tucson gastroenterologist networks. Phase III trial of ursodeoxycholic acid to prevent colorectal adenoma recurrence. J Natl Cancer Inst 97:846-853

Badvie S, Hanna-Morris A, Andreyev HJ, Cohen P, Saini S, AllenMersh TG (2006) A "field change" of inhibited apoptosis occurs in colorectal mucosa adjacent to colorectal adenocarcinoma. J Clin Pathol 59:942-946

Bayerdörffer E, Mannes GA, Ochsenkühn T, Dirschedl P, Wiebecke B, Paumgartner G (1995) Unconjugated secondary bile acids in the serum of patients with colorectal adenomas. Gut 36:268-273

Bernstein C, Bernstein H, Garewal H, Dinning P, Jabi R, Sampliner RE, McCuskey MK, Panda M, Roe DJ, L'Heureux L, Payne C (1999) A bile acid-induced apoptosis assay for colon cancer risk and associated quality control studies. Cancer Res 59:2353-2357

Bernstein H, Holubec H, Warneke JA, Garewal H, Earnest DL, Payne CM, Roe DJ, Cui H, Jacobson EL, Bernstein C (2002) Patchy field defects of apoptosis resistance and dedifferentiation in flat mucosa of colon resections from colon cancer patients. Ann Surg Oncol 9:505-517

Bernstein H, Payne CM, Kunke K, Crowley-Weber CL, Waltmire CN, Dvorakova K, Holubec H, Bernstein C, Vaillancourt RR, Raynes DA, Guerriero V, Garewal H (2004) A proteomic study of resistance to DOC-induced apoptosis. Carcinogenesis 25:681-692

Bernstein H, Bernstein C, Payne CM, Dvorakova K, Garewal H (2005) Bile acids as carcinogens in human gastrointestinal cancers. Mutat Res 589:47-65 
Bernstein H, Holubec H, Bernstein C, Ignatenko N, Gerner E, Dvorak K, Besselsen D, Ramsey L, Dall'Agnol M, Blohm-Mangone KA, Padilla-Torres J, Cui H, Garewal H, Payne CM (2006) Unique dietary-related mouse model of colitis. Inflamm Bowel Dis 12:278-293

Bernstein $\mathrm{H}$, Holubec $\mathrm{H}$, Bernstein $\mathrm{C}$, Ignatenko NA, Gerner E, Dvorak K, Besselsen D, Blohm-Mangone KA, Padilla-Torres J, Dvorakova B, Garewal H, Payne CM (2007) Deoxycholateinduced colitis is markedly attenuated in Nos2 knockout mice in association with modulation of gene expression profiles. Dig Dis Sci 52:628-642

Bernstein H, Bernstein C, Payne CM, Dvorak K (2009) Bile acids as endogenous etiologic agents in gastrointestinal cancer. World $\mathrm{J}$ Gastroenterol 15:3329-3340

Booth LA, Bilton RF (1998) Genotoxic potential of the secondary bile acids: a role for reactive oxygen species. In: Arouma OI, Halliwell B (eds) DNA and free radicals: techniques, mechanisms and applications. OICA International, London, pp 161-177

Booth LA, Gilmore IT, Bilton RF (1997) Secondary bile acid induced DNA damage in HT29 cells: are free radicals involved? Free Radic Res 26:135-144

Butler LM, Wang R, Koh WP, Stern MC, Yuan JM, Yu MC (2009) Marine n-3 and saturated fatty acids in relation to risk of colorectal cancer in Singapore Chinese: a prospective study. Int J Cancer 124:678-686

Casellas F, Mourelle M, Papo M, Guarner F, Antolin M, Armengol JR, Malagelada JR (1996) Bile acid induced colonic irritation stimulates intracolonic nitric oxide release in humans. Gut 38:719-723

Cheah PY (1990) Hypotheses for the etiology of colorectal canceran overview. Nutr Cancer 14:5-13

Clifford MN (1999) Chlorogenic acids and other cinnamates-nature, occurrence and dietary burden. J Sci Food Agric 79:362-372

Craven PA, Pfanstiel J, DeRubertis FR (1986) Role of reactive oxygen in bile salt stimulation of colonic epithelial proliferation. J Clin Invest 77:850-859

Crowley-Weber CL, Payne CM, Gleason-Guzman M, Watts GS, Futscher B, Waltmire CN, Crowley C, Dvorakova K, Bernstein C, Craven M, Garewal H, Bernstein H (2002) Development and molecular characterization of HCT-116 cell lines resistant to the tumor promoter and multiple stress-inducer, deoxycholate. Carcinogenesis 23:2063-2080

Crowley-Weber CL, Dvorakova K, Crowley C, Bernstein H, Bernstein C, Garewal H, Payne CM (2003) Nicotine increases oxidative stress, activates NF-kappaB and GRP78, induces apoptosis and sensitizes cells to genotoxic/xenobiotic stresses by a multiple stress inducer, deoxycholate: relevance to colon carcinogenesis. Chem Biol Interact 145:53-66

Crowther JS, Drasar BS, Hill MJ, Maclennan R, Magnin D, Peach S, Teoh-chan CH (1976) Faecal steroids and bacteria and large bowel cancer in Hong Kong by socio-economic groups. Br J Cancer 34:91-198

Dall'Agnol M, Bernstein C, Bernstein H, Garewal H, Payne CM (2006) Identification of S-nitrosylated proteins after chronic exposure of colon epithelial cells to deoxycholate. Proteomics 6:1654-1662

Drasar BS, Irving D (1973) Environmental factors and cancer of the colon and breast. Br J Cancer 27:167-172

Fang C, Dean J, Smith JW (2007) A novel variant of ileal bile acid binding protein is up-regulated through nuclear factor kappaB activation in colorectal adenocarcinoma. Cancer Res 67:9039-9046

Fernandez-Panchon MS, Villano D, Troncoso AM, Garcia-Parrilla MC (2008) Antioxidant activity of phenolic compounds: from in vitro results to in vivo evidence. Crit Rev Food Sci Nutr 48:649-671

Garewal H, Bernstein H, Bernstein C, Sampliner R, Payne C (1996) Reduced bile acid-induced apoptosis in "normal"colorectal mucosa: a potential biological marker for cancer risk. Cancer Res 56:1480-1483

Glinghammar B, Inoue H, Rafter JJ (2002) Deoxycholic acid causes DNA damage in colonic cells with subsequent induction of caspases, $C O X-2$ promoter activity and the transcription factors NF- $\kappa$ B and AP-1. Carcinogenesis 23:839-845

Hill MJ (1990) Bile flow and colon cancer. Mutat Res 238:313-320

Hill MJ, Drasar BS, Hawksworth G, Aries V, Crowther JS, Williams RE (1971) Bacteria and aetiology of cancer of large bowel. Lancet 1:95-100

Hill MJ, Taylor AJ, Thompson MH, Wait R (1982) Fecal steroids and urinary volatile phenols in four Scandinavian populations. Nutr Cancer 4:67-73

Hursting SD, Thornquist M, Henderson MM (1990) Types of dietary fat and the incidence of cancer at five sites. Prev Med 19:242-253

Jenkins M, Croitoru ME, Monga N, Cleary S, Cotterchio M, Hopper JL, Gallinger S (2006) Risk of colorectal cancer in monoallelic and biallelic carriers of MYH mutations: a population-based case-family study. Cancer Epidemiol Biomarkers Prev 15:312314

Jensen OM, MacLennan R, Wahrendorf J (1982) Diet, bowel function, fecal characteristics, and large bowel cancer in Denmark and Finland. Nutr Cancer 4:5-19

Knox EG (1977) Foods and diseases. Br J Prev Soc Med 31:71-80

La Vecchia C (2009) Association between Mediterranian dietary patterns and cancer risk. Nutr Rev 67(Suppl 1):5126-5129

Lechner S, Muller-Ladner U, Schlottmann K, Jung B, McClelland M, Ruschoff J, Welsh J, Scholmerich J, Kullmann F (2002) Bile acids mimic oxidative stress induced upregulation of thioredoxin reductase in colon cancer cell lines. Carcinogenesis 23:12811288

Longpre JM, Loo G (2008) Protection of human colon epithelial cells against deoxycholate by rottlerin. Apoptosis 13:1162-1171

Mattila P, Kumpulainen J (2002) Determination of free and total phenolic acids in plant-derived foods by HPLC with diode-array detection. J Agric Food Chem 50:3660-3667

McKeown-Eyssen GE, Bright-See E (1984) Dietary factors in colon cancer: international relationships. Nutr Cancer 6:160-170

McSherry CK, Cohen BL, Bokkenheuser VD, Mosbach EH, Winter J, Matoba N, Scholes J (1989) Effects of calcium and bile acid feeding on colon tumors in the rat. Cancer Res 49:6039-6043

Michels KB, Willett WC, Fuchs CS, Giovannucci E (2006) Coffee, tea, and caffeine consumption and incidence of colon and rectal cancer. J Natl Cancer Inst 97:282-292

Miller AB, Howe GR, Jain M, Craib KJ, Harrison L (1983) Food items and food groups as risk factors in a case-control study of diet and colo-rectal cancer. Int J Cancer 32:155-161

Narisawa T, Magadia NE, Weisburger JH, Wynder EL (1974) Promoting effect of bile acids on colon carcinogenesis after intrarectal instillation of $N$-Methyl- $N$ '-nitro- $N$-nitrosoguanidine in rats. J Natl Cancer Inst 53:1093-1097

Newmark HL, Yang K, Lipkin M, Kopelovich L, Liu Y, Fan K, Shinozaki H (2001) A Western-style diet induces benign, malignant neoplasms in the colon of normal C57B1/6 mice. Carcinogenesis 22:871-1875

Newmark HL, Yang K, Kurihara N, Fan K, Augenlicht LH, Lipkin M (2009) Western-style diet-induced colonic tumors and their modulation by calcium and vitamin $\mathrm{D}$ in $\mathrm{C} 57 \mathrm{~B} 1 / 6$ mice: a preclinical model for human sporadic colon cancer. Carcinogenesis 30:88-92 
Noffsinger AE (2009) Serrated polyps and colorectal cancer: new pathway to malignancy. Annu Rev Pathol Mech Dis 4:343-364

Park HJ, Davis SR, Liang HY, Rosenberg DW, Bruno RS (2010) Chlorogenic acid differentially alters hepatic and small intestinal thiol redox status without protecting against azoxymethaneinduced colon carcinogenesis in mice. Nutr Cancer 62:362-370

Payne CM, Bernstein H, Bernstein C, Garewal H (1995) Role of apoptosis in biology and pathology: resistance to apoptosis in colon carcinogenesis. Ultrastruct Pathol 19:221-248

Payne CM, Crowley C, Washo-Stultz D, Briehl M, Bernstein H, Bernstein C, Beard S, Holubec H, Warneke J (1998) The stressresponse proteins poly(ADP-ribose) polymerase and NF-kappaB protect against bile salt-induced apoptosis. Cell Death Differ 5:623-636

Payne CM, Weber C, Crowley-Skillicorn C, Dvorak K, Bernstein H, Bernstein C, Holubec H, Dvorakova B, Garewal H (2007) Deoxycholate induces mitochondrial oxidative stress and activates NF-kappaB through multiple mechanisms in HCT-116 colon epithelial cells. Carcinogenesis 28:215-222

Payne CM, Bernstein C, Dvorak K, Bernstein H (2008) Hydrophobic bile acids, genomic instability, Darwinian selection, and colon carcinogenesis. Clin Exp Gastroenterol 1:19-47

Payne CM, Crowley-Skillicorn C, Holubec H, Dvorak K, Bernstein C, Moyer MP, Garewal H, Bernstein H (2009) Deoxycholate, an endogenous cytotoxin/genotoxin, induces the autophagic stresssurvival pathway: implicationsfor colon carcinogenesis. J Toxicol 2009:785907. Epub 2009 May 10

Payne CM, Crowley-Skillicorn C, Bernstein C, Holubec H, Moyer MP, Bernstein H (2010a) Hydrophobic bile acid-induced mitotic perturbations and micronuclei formation: relevance to genomic instability in colon carcinogenesis. Nutr Cancer 62:825-840

Payne CM, Holubec H, Bhattacharyya AD, Bernstein C, Bernstein H (2010b) Exposure of mouse colon to dietary bile acid supplement induces sessile adenomas. Inflam Bowel Dis 16:729-730

Post SM, de Crom R, van Haperen R, van Tol A, Princen HM (2003) Increased fecal bile acid excretion in transgenic mice with elevated expression of human phospholipid transfer protein. Arterioscler Thromb Vasc Biol 23:892-897

Powolny A, Xu J, Loo G (2001) Deoxycholate induces DNA damage and apoptosis in human colon epithelial cells expressing either mutant or wild-type p53. Int J Biochem Cell Biol 33:193-203

Reddy BS, Wynder EL (1973) Large-bowel carcinogenesis: fecal constituents of populations with diverse incidence rates of colon cancer. J Natl Cancer Inst 50:1437-1442

Reddy BS, Narasawa T, Weisburger JH, Wynder EL (1976) Promoting effect of sodium deoxycholate on colon adenocarcinomas in germfree rats. J Natl Cancer Inst 56:441-442

Reddy BS, Watanabe K, Weisburger JH, Wynder EL (1977) Promoting effect of bile acids in colon carcinogenesis in germfree and conventional F344 rats. Cancer Res 37:3238-3242

Reddy BS, Hedges AR, Laakso K, Wynder EL (1978) Metabolic epidemiology of large bowel cancer: fecal bulk and constituents of high-risk North American and low-risk Finnish population. Cancer 42:2832-2838

Reddy BS, Hanson D, Mangat S, Mathews L, Sbaschnig M, Sharma C, Simi B (1980) Effect of high-fat, high-beef diet and of mode of cooking of beef in the diet on fecal bacterial enzymes and fecal bile acids and neutral sterols. J Nutr 110:1880-1887

Reddy S, Sanders TA, Owen RW, Thompson MH (1998) Faecal pH, bile acid and sterol concentrations in premenopausal Indian and white vegetarians compared with white omnivores. Br J Nutr 79(6):495-500

Romagnolo DF, Chirnomas RB, Ku J, Jeffy BD, Payne CM, Holubec H, Ramsey L, Bernstein H, Bernstein C, Kunke K, Bhattacharyya A, Warneke J, Garewal H (2003) Deoxycholate, an endogenous tumor promoter and DNA damaging agent, modulates BRCA-1 expression in apoptosis-sensitive epithelial cells: loss of BRCA-1 expression in colonic adenocarcinomas. Nutr Cancer 46:82-92

Rosignoli P, Fabiani R, De Bartolomeo A, Fuccelli R, Pelli MA, Morozzi G (2008) Genotoxic effect of bile acids on human normal and tumour colon cells and protection by dietary antioxidants and butyrate. Eur J Nutr 47:301-309

Sakamoto K, Tominaga Y, Yamauchi K, Nakatsu Y, Sakumi K, Yoshiyama K, Egashira A, Jura S, Yao T, Tsuneyoshi M, Maki H, Nakabeppu Y, Tsuzuki T (2007) MUTYH-Null mice are susceptible to spontaneous and oxidative stress-induced intestinal tumorigenesis. Cancer Res 67:6599-6604

Samuel P, Saypoi GM, Meilman E, Mosbach EH, Chafizadeh M (1968) Absorption of bile acids from the large bowel in man. J Clin Invest 47:2070-2078

Spring KJ, Zhao ZZ, Karamatic R, Walsh MD, Whitehall VL, Pike T, Simms LA, Young J, James M, Montgomery GW, Appleyard M, Hewett D, Togashi K, Jass JR, Leggett BA (2006) High prevalence of sessile serrated adenomas with BRAF mutations: a prospective study of patients undergoing colonoscopy. Gastroenterology 131:1400-1407

Stadler J, Stern HS, Yeung KS, McGuire V, Furrer R, Marcon N, Bruce WR (1988) Effect of high fat consumption on cell proliferation activity of colorectal mucosa and on soluble faecal bile acids. Gut 29:1326-1331

Tang YZ, Liu ZQ (2008) Chemical kinetic behavior of chlorogenic acid in protecting erythrocyte and DNA against radical-induced oxidation. J Agric Food Chem 56:11025-11029

Tavani A, Pelucchi C, Parpinel M, Negri E, Franceschi S, Levi F, La Vecchia C (2003) N-3 polyunsaturated fatty acid intake and cancer risk in Italy and Switzerland. Int J Cancer 105:113-116

Thomas LA, Veysey MJ, French G, Hylemon PB, Murphy GM, Dowling RH (2001) Bile acid metabolism by fresh human colonic contents: a comparison of caecal versus faecal samples. Gut 49:835-842

Venturi M, Hambly RJ, Glinghammar B, Rafter JJ, Rowland IR (1997) Genotoxic activity in human faecal water and the role of bile acids: a study using the alkaline comet assay. Carcinogenesis 18:2353-2359

Wasan HS, Novelli M, Bee J, Bodmer WF (1997) Dietary fat influences on polyp phenotype in multiple intestinal neoplasia mice. Proc Natl Acad Sci USA 94:3308-3313

Washo-Stultz D, Hoglen N, Bernstein H, Bernstein C, Payne CM (1999) Role of nitric oxide and peroxynitrite in bile salt-induced apoptosis: relevance to colon carcinogenesis. Nutr Cancer $35: 180-188$

Washo-Stultz D, Crowley-Weber CL, Dvorakova K, Bernstein C, Bernstein H, Kunke K, Waltmire CN, Garewal H, Payne CM (2002) Role of mitochondrial complexes I and II, reactive oxygen species and arachiddonic acid metabolism in deoxycholate-induced apoptosis. Cancer Lett 177:129-144

Wertheim BC, Martínez ME, Ashbeck EL, Roe DJ, Jacobs ET, Alberts DS, Thompson PA (2009) Physical activity as a determinant of fecal bile acid levels. Cancer Epidemiol Biomarkers Prev 18:1591-1598

Willett W (1989) The search for the causes of breast and colon cancer. Nature 338:389-394

Willett WC, Stampfer MJ, Colditz GA, Rosner BA, Speizer FE (1990) Relation of meat, fat, and fiber intake to the risk of colon cancer in a prospective study among women. N Engl J Med 323:1664-1672

Yang K, Kurihara N, Fan K, Newmark H, Rigas B, Bancroft L, Corner G, Livote E, Lesser M, Edelmann W, Velcich A, Lipkin M, Augenlicht L (2008) Dietary induction of colonic tumors in a mouse model of sporadic colon cancer. Cancer Res 68:78037810 